\author{
JOLANTA BEHR \\ ORCID: 0000-0002-2688-2836 \\ Uniwersytet Wrocławski \\ jolanta.behr2@uwr.edu.pl
}

\title{
Usługi publiczne w czasie pandemii COVID-19*. Analiza z uwzględnieniem specyfiki świadczenia usług niematerialnych
}

\begin{abstract}
Abstrakt: Pandemia COVID-19 jest jedną z wielu pandemii, z którymi ludzkość będzie musiała się zmierzyć w nieodległym czasie. Wywiera ona wpływ na funkcjonowanie podmiotów publicznych i stosunki społeczne. Jednym z obszarów najbardziej dotkniętym jej skutkami są usługi niematerialne, których świadczenie należy do głównych zadań związków publicznoprawnych, czyli jednostek samorządu terytorialnego. Sposób i zakres świadczenia usług publicznych uległ istotnej zmianie. $\mathrm{Z}$ powodu ryzyka wystąpienia kolejnych pandemii, ważne jest zidentyfikowanie jak największej liczby problemów i wyzwań związanych $\mathrm{z}$ tą sferą oraz wypracowanie skutecznych ich rozwiązań, aby podmioty publiczne były jak najlepiej przygotowane do funkcjonowania w trudnych warunkach, a jednocześnie by nie były naruszane prawa i wolności człowieka i obywatela. W pracy wskazano główne problemy związane ze świadczeniem usług niematerialnych w czasie pandemii i zaproponowano sposoby ich rozwiązania.
\end{abstract}

Słowa kluczowe: związki publicznoprawne, pandemia COVID-19, usługi publiczne, usługi niematerialne, wykluczenie usługowe, problemy, postulaty de lege ferenda.

* Zastosowane w tytule określenie „pandemia COVID-19” dotyczy pandemii potwierdzonej przez Światową Organizację Zdrowia w dniu 11 marca 2020 r., jest to zatem pojęcie medyczne (WHO Director-General's opening remarks at the media briefing on COVID-19-7 September 2020, https://www.who.int/director-general/speeches/detail/who-director-general-s-opening-remarks-at-the-media-briefing-on-covid-19---7-september-2020, dostęp: 30.04.2021). Jeśli idzie o kontekst prawny (krajowy) - praca dotyczy stanu epidemii uregulowanego rozporządzeniem Ministra Zdrowia z 20 marca 2020 roku w sprawie ogłoszenia na obszarze Rzeczypospolitej Polskiej stanu epidemii (Dz.U. poz. 491 ze zm.), który poprzedzał stan zagrożenia epidemicznego (zob. rozporządzenie Ministra Zdrowia z 13 marca 2020 roku w sprawie ogłoszenia na obszarze Rzeczypospolitej Polskiej stanu zagrożenia epidemicznego, Dz.U. poz. 433 ze zm.). 


\section{Wstęp}

Administracja publiczna jest coraz częściej określana mianem administracji usług ${ }^{1}$. Główni organizatorzy usług publicznych to związki publicznoprawne, w postaci jednostek samorządu terytorialnego, omawiane szeroko przez Tadeusza Bigę $^{2}$. I chociaż w czasach, w których Autor analizował te podmioty, obowiązywały inne przepisy prawa, inna również była struktura samorządu terytorialnego, to rozważania dotyczące jego istoty i zadan - w tym usług publicznych ${ }^{3}-$ pozostają aktualne. Także i dziś do zadań jednostek samorządu terytorialnego należy nieprzerwane świadczenie określonych ustawami usług materialnych ${ }^{4}$ i niematerialnych ${ }^{5}$, których beneficjentem jest każdy z nas, ponadto zaś zapewnienie odpowiednich warunków do ich świadczenia ${ }^{6}$. Nawet jeśli jednostki te zlecają wykonywanie zadań z tego zakresu innym podmiotom, w tym niepublicznym, nadal pełnią rolę gwaranta ich właściwej realizacji ${ }^{7}$.

Sposób i zakres świadczenia usług publicznych podlega ciągłym zmianom. Ma na to wpływ wiele czynników, obiektywnych i subiektywnych; niektóre z nich są zależne od administracji publicznej, na inne nie ma ona natomiast wpływu. Ogół czynników to przede wszystkim: dynamiczny rozwój nowych technologii,

1 Z. Niewiadomski, Uwarunkowania ksztattu wspótczesnej administracji publicznej, [w:] System Prawa Administracyjnego, t. 1. Instytucje prawa administracyjnego, red. R. Hauser, Z. Niewiadomski, A. Wróbel, Warszawa 2010, s. 21.

2 T. Bigo, Związi publiczno-prawne $w$ świetle ustawodawstwa polskiego, Warszawa 1928 , s. $55-64$

3 Ibidem, s. 59.

${ }^{4}$ Do materialnych zalicza się między innymi: doprowadzanie wody i odprowadzanie ścieków, transport publiczny, dostarczanie energii elektrycznej, cieplnej i gazu oraz odbiór i utylizowanie odpadów komunalnych.

${ }^{5}$ Są to przede wszystkim usługi z zakresu: oświaty, kultury, kultury fizycznej i turystyki oraz zdrowia.

${ }^{6}$ Szerzej zob. T. Kuta, Rola administracji ustug $w$ zaspokajaniu potrzeb socjalno-bytowych i oświatowokulturalnych obywateli, [w:] Administracja publiczna u progu XXI wieku: prace dedykowane prof. zw. dr hab. Janowi Szreniawskiemu z okazji Jubileuszu 45-lecia pracy naukowej, red. Z. Niewiadomski et al., Przemyśl 2000; J. Behr, Gmina jako podmiot administracji świadczącej w zakresie ustug niematerialnych, Warszawa 2019, s. 33-40; J. Posłuszny, Istota i cechy administracji świadczącej, „Administracja: teoria, dydaktyka, praktyka” 2005, nr 1; J. Posłuszny, Ewolucja administracji świadczącej (na przykładzie szkolnictwa wyższego). Studium administracyjnoprawne, Rzeszów-Przemyśl 2004; I. Lipowicz, Samorząd terytorialny jako podmiot administracji świadczącej, „Ruch Prawniczy, Ekonomiczny i Socjologiczny” 2015, z. 3.

${ }^{7}$ Szerzej zob. J. Behr, Prywatyzacja ustug gminnych, [w:] Efektywność ekonomiczna jako cel prywatyzacji zadań z zakresu administracji świadczącej: studium administracyjno-prawne, red. J. Blicharz, R. Raszewska-Skałecka, Wrocław 2020, s. 53-71; eadem, Udziat trzeciego sektora $w$ świadczeniu gminnych usług niematerialnych, [w:] Trzeci sektor i ekonomia społeczna: uwarunkowania prawne. Kierunki działań, red. J. Blicharz, L. Zacharko, Wrocław 2017, s. 65-75.

Prawo 333, 2021

(C) for this edition by CNS 
zmienne preferencje usługobiorców oraz presja społeczeństwa oczekującego od administracji publicznej przejmowania do zrealizowania coraz to nowych zadań i świadczenia kolejnych usług powszechnie dostępnych.

Przyczyn zmian można poszukiwać również w ramach administracji publicznej, która dąży do zwiększenia efektywności podejmowanych działań, optymalizacji procesów oraz do generowania oszczędności, niezbędnych do wykonywania innych zadań publicznych.

Różnice wynikają niekiedy także ze zmian podmiotów świadczących usługi. Prywatyzowanie zadań z tego obszaru, polegające na odstąpieniu od bezpośredniego świadczenia usług przez podmioty publiczne na rzecz podmiotów niepublicznych ${ }^{8}$, skutkuje niejednokrotnie oferowaniem innego zakresu usług i zmianą dotychczasowej formy ich świadczenia.

Źródłem różnic mogą być ponadto czynniki zewnętrzne i niezależne względem usługodawców i usługobiorców. Należy do nich, niewątpliwie, pandemia COVID-19, której skutki są wielopostaciowe i długofalowe. Można je zaobserwować w zasadzie w każdym obszarze funkcjonowania państwa i społeczeństwa. Dotyczą one pojedynczych osób, oddziałując na sposób wykonywania przez nie pracy, dysponowanie majątkiem, spędzanie wolnego czasu oraz nawiązywanie relacji. Oddziałują również globalnie, wpływając na gospodarkę, inicjując dynamiczny i kierunkowy rozwój nowych technologii oraz niektórych dziedzin nauki, a także skłaniając rządzących do przemyśleń odnośnie do zakresu i formy wykonywania zadań publicznych, które w wielu przypadkach nie są już wystarczające.

Obecna pandemia spowodowała rewolucyjne zmiany, zmuszając nas do wypracowania nowych i trwałych rozwiązań, umożliwiających funkcjonowanie w trudnych realiach. Ustalenie właściwych form i przewidywalnych procedur działania zyskało na znaczeniu po wypowiedzi Dyrektora Generalnego Światowej Organizacji Zdrowia, Tedrosa Adhanoma Ghebreyesusa, który dostrzega ryzyko wystąpienia kolejnych, bardziej dotkliwych w skutkach, pandemii w nieodległej przyszłości i rekomenduje podjęcie działań mających na celu poprawę systemu zdrowia publicznego i doinwestowywanie podmiotów publicznych, realizujących zadania z tego zakresu ${ }^{9}$. W kontekście tych stwierdzeń ważne jest wnikliwe obserwowanie rzeczywistości i zidentyfikowanie jak największej liczby negatywnych następstw pandemii, aby było możliwe wypracowanie skutecznych rozwiązań na przyszłość.

${ }^{8}$ Zob. S. Biernat, Prywatyzacja zadań publicznych. Problematyka prawna, Warszawa-Kraków 1994, s. 25 n.

9 WHO Director-General's opening... 


\section{1. Świadczenie usług publicznych w czasie pandemii COVID-19}

Wspomniane rozwiązania powinny dotyczyć również usług publicznych. Obszar ten ma szczególne znaczenie, ponieważ beneficjentem rzeczonych usług jest każdy z nas. Skutki pandemii dotknęły go w różnym zakresie, co było zależne przede wszystkim od rodzaju określonej usługi. Mniejsze oddziaływanie występuje w sferze usług materialnych. W usługach niewymagających bezpośredniego kontaktu jest znikome. Przykładem są zadania z zakresu zbiorowego zaopatrzenia w wodę i zbiorowego odprowadzania ścieków ${ }^{10}$.

Inaczej sytuacja wygląda w przypadkach, gdy warunkiem sine qua non świadczenia usługi jest jednoczesna obecność usługodawcy ${ }^{11}$ i usługobiorcy oraz korzystanie z określonego rodzaju infrastruktury. Do przykładów należy transport zbiorowy $^{12}$, gdzie nie można świadczyć usług inaczej, jak tylko w sposób bezpośredni. Ścisły związek z infrastrukturą wymusza zatem dostosowanie zakresu i sposobu świadczonych usług do warunków pandemicznych. Inaczej organizuje się przestrzeń w pojazdach, wyłącza się niektóre strefy z użytkowania oraz wprowadza limity osób mogących jednocześnie korzystać z oferowanych usług, w sposób zapewniający zachowanie reżimu sanitarnego. W związku z tym zmianie ulega również częstotliwość świadczenia usług, konieczne było bowiem wprowadzenie dodatkowych przewozów, aby w pełni zaspokoić potrzeby usługobiorców.

Największe oddziaływanie występuje natomiast w zakresie usług niematerialnych, ponieważ przyjęto, że można je skutecznie świadczyć bez jednoczesnej obecności usługodawcy i usługobiorcy - na odległość, zdalnie. Zdecydowano o czasowym zamknięciu lub ograniczeniu korzystania z zakładów administracyjnych, co uzasadniano zapewnieniem ochrony zdrowia i życia mieszkańców. W niektórych przypadkach uregulowano prawnie korzystanie z usług z zastosowaniem Internetu ${ }^{13}$. Dokonano zatem istotnych modyfikacji w formie i zakresie świadczenia usług.

10 Należą one do zadań własnych gminy, określonych w art. 3 ustawy z dnia 7 czerwca 2001 roku o zbiorowym zaopatrzeniu w wodę i zbiorowym odprowadzaniu ścieków (tekst jedn. Dz.U. z 2020 r. poz. 2028).

11 Określenie „usługodawca” jest pewnym uproszczeniem. Chodzi o osobę upoważnioną do podejmowania działań w imieniu i na rzecz usługodawcy.

12 Zob. zadania związane ze świadczeniem usług w ramach transportu zbiorowego, określone w ustawie z dnia 16 grudnia 2010 roku o publicznym transporcie zbiorowym (tekst jedn. Dz.U. z 2020 r. poz. 1944 ze zm.).

13 Zob. np. ustawa z dnia 2 marca 2020 roku o szczególnych rozwiązaniach związanych z zapobieganiem, przeciwdziałaniem i zwalczaniem COVID-19, innych chorób zakaźnych oraz wywołanych nimi sytuacji kryzysowych (Dz.U. poz. 1842 ze zm.) oraz liczne rozporządzenia z tego zakresu. 
W pierwszej fazie pandemii podejmowane były działania polegające przede wszystkim na zapewnieniu dostępności usług hybrydowych, a więc tych, z których korzystanie jest jednocześnie prawem i obowiązkiem usługobiorcy, a zagwarantowanie ich dostępności jest obowiązkiem władz publicznych ${ }^{14}$. Dążono również do zagwarantowania dostępności usług podstawowych, czyli tych, dla których świadczenia zostały utworzone zakłady administracyjne ${ }^{15}$.

Mniejszą uwagę przywiązywano natomiast do prawnego uregulowania i zapewnienia faktycznej dostępności usług dodatkowych, a więc tych, które są świadczone ponad podstawowy zakres usług oferowanych w danym zakładzie administracyjnym. Przyczynił się do tego szeroki zakres spraw poddanych regulacji, krótki czas na przyjęcie nowych unormowań — utrudniający prowadzenie wszechstronnych analiz — oraz nieprzewidywalny rozwój sytuacji. Pandemia uwypukliła bowiem liczne problemy systemowe i nasiliła skutki wieloletnich zaniedbań, wymuszając podjęcie wieloobszarowych i skoordynowanych działań. Prowadzone są one równolegle $\mathrm{z}$ działaniami zmierzającymi do zapewnienia ochrony zdrowia i życia mieszkańców, w które są zaangażowane różne typy związków publicznoprawnych, w tym jednostki samorządu terytorialnego i samorządy zawodów medycznych ${ }^{16}$.

$\mathrm{Na}$ ograniczeniach w dostępie do usług dodatkowych ucierpiały najbardziej osoby słabsze ${ }^{17}$. Sytuacja zwiększyła różnice w społeczeństwie, pogłębiając wykluczenie społeczne tych osób i zmuszając je do poszukiwania wsparcia poza

14 Obowiązek ten wynika najczęściej z Konstytucji Rzeczypospolitej Polskiej z dnia 2 kwietnia 1997 roku (Dz.U. Nr 78, poz. 483 ze zm.) i aktów prawa międzynarodowego. Przykładem są usługi edukacyjne świadczone przez jednostki systemu oświaty, do korzystania z których są zobowiązane określone przepisami prawa osoby. Podstawy prawne ich świadczenia omówiono w: J. Behr, Prawo do nauki w podmiotach leczniczych: analiza na przyktadzie publicznej szkoły podstawowej specjalnej, „Folia Iuridica Universitatis Wratislaviensis” 5, 2016, nr 2, s. 168-171.

15 Usługi podstawowe są kluczowe dla danego zakładu administracyjnego. Przykładowo, usługami podstawowymi w jednostkach systemu oświaty będą usługi edukacyjne, a usługami dodatkowymi — których zapewnienie jest jednak obligatoryjne dla niektórych osób — zajęcia rewalidacyjne, wspomagające kształcenie i zmierzające do poprawy ogólnej sprawności oraz umiejętności ucznia. Zajęcia rewalidacyjne określa rozporządzenie Ministra Edukacji Narodowej z dnia 9 sierpnia 2017 roku w sprawie warunków organizowania kształcenia, wychowania i opieki dla dzieci i młodzieży niepełnosprawnych, niedostosowanych społecznie i zagrożonych niedostosowaniem społecznym (tekst jedn. Dz.U. z 2020 r. poz. 1309). Innym przykładem usług podstawowych są usługi kulturalne świadczone w teatrach (spektakle), obok których świadczone są usługi edukacyjne i wychowawcze (półkolonie dla dzieci organizowane w tych zakładach).

16 Szerzej na ich temat zob. T. Bigo, op. cit., s. 104-107.

17 Przykładowo, niektórym uczniom z niepełnosprawnościami ograniczono dostęp do zajęć rewalidacyjnych (zob. wystąpienie Rzecznika Praw Obywatelskich: Edukacja w czasie pandemii dyskryminuje dzieci i młodzież z niepetnosprawnościami - RPO wystapił do MEiN, https:// www.rpo.gov.pl/pl/content/edukacja-dyskryminujaca-dzieci-i-mlodziez-z-niepelnosprawnosciami-w-czasie-pandemii, dostęp: 30.04.2021), a uczniom zmagającym się z trudnymi sytuacjami życiowymi ograniczono możliwość bezpośredniego kontaktu z psychologiem szkolnym. Mimo zagwarantowania formalnego kontaktu z psychologiem, wielu uczniów zrezygnowało z korzystania 
zinstytucjonalizowanym, publicznym systemem usług publicznych. Wiązało się to z koniecznością ponoszenia dodatkowych opłat, co stanowiło istotną barierę w dostępie dla wielu osób.

\section{Usługi niematerialne w czasie pandemii COVID-19}

Cechą usług niematerialnych jest świadczenie ich w sposób bezpośredni, w ramach zakładu administracyjnego, z którego korzystają tylko jego użytkownicy. W wielu zakładach — z uwagi na ciągłość i regularność korzystania z usług wytwarza się wśród użytkowników, a także między nimi a pracownikami zakładu, określona relacja (więź). Jest ona unikalna, bowiem nie występuje w obszarze usług materialnych, świadczonych w innych formach organizacyjnoprawnych ${ }^{18}$. Zatem nie bez powodu już w pierwszych definicjach zakładu administracyjnego akcentowano jedność „osób, rzeczy i praw” "19. Jedność ta jest bowiem kwintesencją istnienia zakładu administracyjnego, którego celem jest nie tylko świadczenie usług jego użytkownikom, lecz także umożliwienie im nawiązania trwałej relacji, przekazywania wzorców prawidłowego postępowania, wzajemnego wspierania się oraz budowania na wspólnym fundamencie wiedzy, umiejętności i doświadczeń poprzednich pokoleń.

Tak pojmowany zakład administracyjny nie może zostać skutecznie i ostatecznie zastąpiony żadną inną formą prawną, a w szczególności uniemożliwiającą nawiązanie bezpośredniego kontaktu między osobami. W warunkach wymuszających izolację konieczne jest jednak stosowanie alternatywnych form i narzędzi stwarzających możliwość świadczenia tych usług za pośrednictwem Internetu. W skrajnych przypadkach — w szczycie zachorowań — są one niewątpliwie pożyteczne dla ogółu i powinny być wykorzystywane na szeroką skalę.

Warto jednak pamiętać, że zdalne nauczanie, wirtualne muzea, interaktywne czytelnie i biblioteki, zdalne koła rozwijania pasji oraz leczenie $\mathrm{w}$ formie teleporady nigdy nie zastąpią w pełni bezpośredniego kontaktu z osobą ani dziełem. W wirtualnym świecie nie stworzymy odpowiedniej atmosfery, nie odczytamy właściwie sygnałów niewerbalnych ani nie dostrzeżemy niepokojących zachowań, na które powinniśmy w porę zareagować.

z tej formy wsparcia z powodu braku warunków lokalowych. Dzieci niechętnie opowiają o problemach w towarzystwie współdomowników.

18 Na temat przedsiębiorstw typu zakładowego zob. T. Kuta, Administracja usług, Poznań 2000, s. 25-27.

19 W. Klonowiecki, Zakład publiczny w prawie polskiem. Studjum prawo-administracyjne, Lublin 1933, s. 74. 
W świecie tym nie jest również możliwe świadczenie niektórych rodzajów usług bez istotnego uszczerbku dla dobra i interesu usługobiorcy. Dotyczy to przede wszystkim usług zdrowotnych, które w czasie pandemii uległy polaryzacji. Znaczenie priorytetowe przyznano usługom zmierzających do ochrony zdrowia i życia mieszkańców w związku z zakażeniem wirusem SARS-CoV-2 oraz usługom medycyny ratunkowej, jednocześnie można odnotować trudności w dostępie do pozostałych usług, w szczególności związanych z długotrwałym leczeniem chorób niezakaźnych oraz diagnozowaniem nowych przypadków. Stanowiło to problem w skali globalnej, podobnie jak realizacja praw pacjenta do kontaktu z innymi osobami ${ }^{20}$.

Stosowanie formy zdalnej przez dłuższy czas prowadzi ponadto do wielu problemów, przede wszystkim wśród osób najmłodszych oraz tych, które były dotychczas aktywne fizycznie. Coraz częściej zwraca się uwagę na „pandemiczną otyłość”, pogłębiające się problemy ze zdrowiem psychicznym oraz uzależnienie od Internetu ${ }^{21}$. Ograniczeniu ulegają także kontakty towarzyskie, a ludzie niechętnie angażują się w rozwiązywanie problemów społecznych ${ }^{22}$ i partycypację społeczną ${ }^{23}$.

Zdalna forma świadczenia usług nie dorównuje również formie tradycyjnej pod względem jakości i efektywności. Potwierdzają to dotychczasowe doświadczenia. Dotyczy to przede wszystkim zdalnego nauczania, w obszarze którego problem został już dostrzeżony przez rządzących. W związku z tym planowane jest ograniczenie wymogów egzaminacyjnych i wprowadzenie dodatkowych lekcji celem wyrównania poziomu ${ }^{24}$. Obniżanie wymogów - związane z niższym poziomem świadczenia usług — jest działaniem doraźnym, nie powinno być jednak regułą. Zależy nam bowiem na świadczeniu usług na jak najwyższym poziomie. Ponadto zdalna forma świadczenia usług pozbawia niekiedy usługobiorców możliwości korzystania z usług dodatkowych, zgodnych z ich zainteresowaniami i przyczyniającymi się do ich wszechstronnego rozwoju.

20 Zob. np. A.R. Jazieh et al., Impact of the COVID-19 Pandemic on Cancer Care: A Global Collaborative Study, „JCO Global Oncollogy” 2020, nr 6, s. 1428-1438; Rzecznik Praw Pacjenta, Prawa pacjenta w czasie COVID-19 zostaty ograniczone, https://www.gov.pl/web/rpp/do-rzeczy-rzecznik-praw-pacjenta-prawa-pacjenta-w-okresie-covid-19-zostaly-ograniczone (dostęp: 9.07.2021). Prawa pracjenta, o których mowa, reguluje art. $5 \mathrm{i}$ art. 33 ustawy z dnia 6 listopada 2008 roku o prawach pacjenta i Rzeczniku Praw Pacjenta (tekst jedn. Dz.U. z 2020 r. poz. 849 ze zm.).

${ }^{21}$ Dlugotrwate nauczanie zdalne $w$ szkołach $i$ uczelniach źle wplywa na psychike młodych ludzi, https://naukawpolsce.pap.pl/aktualnosci/news\%2C87027\%2Cekspertka-dlugotrwale-nauczanie-zdalne-w-szkolach-i-uczelniach-zle-wplywa-na (dostęp: 30.04.2021).

${ }^{22} \mathrm{~K}$. Jaśko, Wpływ pandemii COVID-19 na chęć zaangażowania się na rzecz problemów społecznych, https://www.ncn.gov.pl/sites/default/files/pliki/covid_jasko_pl.pdf (dostęp: 30.04.2021).

23 M. Bazylak et al., Partycypacja spoteczna $w$ samorzadzie terytorialnym $w$ czasie epidemii i po, „Alert Samorządowy” 2020, nr 6, s. 1-10.

${ }^{24}$ Środki finansowe na dodatkowe zajęcia wspomagajace dla uczniów po powrocie do szkót z nauki zdalnej, https://www.gov.pl/web/edukacja-i-nauka/srodki-finansowe-na-dodatkowe-zajecia-wspomagajace-dla-uczniow-po-powrocie-do-szkol-z-nauki-zdalnej (dostęp: 30.04.2021). 
Problemem o fundamentalnym znaczeniu w zakresie świadczenia usług w formie zdalnej okazała się jednak ich dostępność. Mimo wdrożenia licznych programów ${ }^{25}$, których celem było zagwarantowanie dostępu do Internetu jak największej liczbie mieszkańców naszego kraju, nadal określona część gospodarstw domowych jest go pozbawiona ${ }^{26}$. W czasie pandemii coraz częściej dostrzega się występowanie wykluczenia cyfrowego, uniemożliwiającego osobom nim dotkniętym korzystanie z usług publicznych. Wśród głównych barier przyczyniających się do jego powstania i utrwalenia wskazuje się: brak odpowiedniego sprzętu, problemy lub ograniczenia w dostępie do Internetu, brak odpowiednich kompetencji, brak odpowiednich warunków do korzystania ze sprzętu oraz ograniczony dostęp do usług i zasobów edukacyjnych ${ }^{27}$.

Dostrzeżone problemy występują przede wszystkim po stronie usługobiorców. Równie istotne są jednak ograniczenia, których źródłem są podmioty świadczące usługi, bowiem oddziałują one na szeroką grupę usługobiorców. Zakłady administracyjne nie są zasadniczo przygotowane do funkcjonowania $\mathrm{w}$ zmienionej formie. W ograniczonym zakresie korzystały one dotychczas z nowych technologii, a ich pracownicy nie zawsze posiadają wymagane przeszkolenie, ułatwiające im wykonywanie pracy w formie zdalnej. Niezbyt często decydowano się ponadto na realizowanie projektów mających na celu ,przeniesienie" usług do Internetu. W ograniczonym zakresie korzystano również z oprogramowania, umożliwiającego podejmowanie tych działań. Istotne zmiany w tym obszarze nastąpiły dopiero w ostatnim czasie ${ }^{28}$.

\section{Podsumowanie}

Opisane problemy nie są możliwe do wyeliminowania w nieodległym czasie z uwagi na ich zakres i skomplikowanie. Wymagają one podjęcia zrównoważonych i długofalowych działań, faktycznych i prawnych. Istotnym wyzwaniem w tym obszarze jest umiejętne ważenie kolidujących wartości i dóbr oraz ustalenie pierwszeństwa niektórych z nich, z uwzględnieniem konstytucyjnej zasady

25 Sztandarowym jest program Polska Cyfrowa (zob. https://www.polskacyfrowa.gov.pl/).

$26 \mathrm{~W}$ ostatnich latach nastąpiło zwiększenie odsetka gospodarstw domowych posiadających dostęp do Internetu. Wynosi on obecnie $90,4 \%$. Statystycznie nadal jednak niemal co dziesiąta osoba jest pozbawiona dostępu do niego w miejscu zamieszkania (Główny Urząd Statystyczny. Urząd Statystyczny w Szczecinie, Społeczeństwo informacyjne w Polsce w 2020 r., Warszawa-Szczecin 2020, s. 24).

27 Problem wykluczenia cyfrowego w edukacji, „Ekspertyza” 3, s. 4-6, https://oees.pl/wp-content/uploads/2020/04/Ekspertyza-3.pdf (dostęp: 30.04.2021).

${ }_{28}$ Zob. przykładowo: konwersje cyfrowe domów kultury, digitalizacje i archiwizacje zbiorów muzealnych, projekt e-zdrowie, wprowadzenie awatara opiekuna osoby starszej, udostępnianie samorządowych aplikacji mobilnych oraz samorządowych centrów e-usług. 
proporcjonalności ${ }^{29}$. Dotyczy to przede wszystkim występującego w tym zakresie konfliktu konstytucyjnego prawa do ochrony zdrowia (art. 68 Konstytucji RP) z innymi konstytucyjnymi prawami i wolnościami człowieka i obywatela.

Kolejną trudnością jest dynamika zmian w tym obszarze. $Z$ uwagi na to, że nie da się a priori przewidzieć rozwoju sytuacji pandemicznej, wszelkie zmiany muszą być wprowadzane z uwzględnieniem aktualnej liczby zachorowań, stopnia zagrożenia zdrowia i życia mieszkańców oraz możliwości osobowych, finansowych i organizacyjnych podmiotów świadczących usługi publiczne, przy czym niekiedy konieczne jest niezwłoczne ich wprowadzenie. W tym kontekście szczególnego znaczenia nabiera uwzględnienie zasady ochrony zaufania obywateli do państwa i stanowionego przez nie prawa ${ }^{30}$ oraz zasady ochrony praw słusznie nabytych $^{31}$, aby w jak najpełniejszym zakresie zabezpieczyć prawa i wolności człowieka i obywatela.

Należy ponadto dołożyć wszelkich starań, aby zagwarantować powszechną dostępność usług $\mathrm{w}$ warunkach izolacji, a więc wyeliminować wykluczenie usługowe. Należy ustalić odpowiedni i — w miarę możliwości — przewidywalny zakres i sposób ich świadczenia, aby dynamiczne zmiany z nimi związane nie zaskakiwały usługodawców ani usługobiorców. Szczególne starania powinny być poczynione w zakresie zapewnienia dostępności wszystkich usług zdrowotnych, a nie tylko tych związanych ze zwalczaniem skutków zakażeniem wirusa SARS-CoV-2.

Oprócz tego, należy zadbać o wypracowanie odpowiednich mierników kontroli, umożliwiających weryfikowanie jakości świadczenia usług, aby móc odpowiednio wcześnie skorygować wadliwe działania.

Równie ważną kwestią jest dążenie do wyeliminowania wykluczenia cyfrowego, które w czasie pandemii skutkuje bezpośrednio wykluczeniem usługowym, czyli uniemożliwieniem korzystania z innych rodzajów usług. W tym obszarze priorytetem jest zapewnienie dostępu do Internetu jak największej liczbie gospodarstw domowych oraz zagwarantowanie jego odpowiedniej szybkości, umożliwiającej równoległe korzystanie z usług przez większą liczbę osób. Ponadto, konieczne jest podejmowanie działań mających na celu podnoszenie kompetencji cyfrowych osób szczególnie narażonych na wykluczenie w tym obszarze ${ }^{32}$.

${ }^{29} \mathrm{Na}$ temat ważenia wartości i dóbr zob. A. Śledzińska-Simon, Analiza proporcjonalności ograniczeń konstytucyjnych praw $i$ wolności. Teoria i praktyka, Wrocław 2019.

30 Zob. np. wyrok Trybunału Konstytucyjnego z dnia 25 czerwca 2002 roku, sygn. K 45/01; wyrok Trybunału Konstytucyjnego z dnia 14 czerwca 2000 roku, sygn. P 3/00; wyrok Trybunału Konstytucyjnego z dnia 20 listopada 1988 roku, sygn. K 1/88.

31 Zob. np. I. Niżnik-Dobosz, Zasada ochrony praw stusznie nabytych, [w:] Środki ochrony praw stusznie nabytych $w$ świetle Konstytucji RP i prawa Unii Europejskiej, red. P. Chmielnicki, H. Zięba-Załucka, Warszawa 2012; J. Zimmermann, Zasada ochrony praw dobrze (stusznie) nabytych, [w:] Prawo administracyjne, Warszawa 2016, s. 164.

32 Są nimi w szczególności seniorzy (zob. D. Rak, M. Petrowicz, W. Pokojska, Potrzeby szkoleniowe $i$ kompetencje seniorów $w$ zakresie korzystania z internetu, [w:] Inspiracje i innowacje: 
Kolejną sprawą jest systematyczne podejmowanie działań mających na celu zapewnienie dostępności usług niematerialnych w formie zdalnej. Szczególnie istotne $\mathrm{w}$ tym obszarze jest nabycie przez zakłady administracyjne odpowiedniego oprogramowania ułatwiającego pracę zdalną oraz zwiększenie kompetencji cyfrowych pracowników w formie kursów i szkoleń, aby mogli odpowiednio realizować nałożone na nich zadania. Nie mniej ważne jest realizowanie projektów zmierzających do „przenoszenia” usług niematerialnych do sieci. Należy zadbać o zapewnienie odpowiedniej infrastruktury cyfrowej oraz — jeśli pozwala na to charakter usług - umożliwić korzystanie z nich w każdym czasie. Przyczyni się to do złagodzenia skutków czasowego ograniczenia dostępu do Internetu. W tym zakresie można skorzystać z dotychczasowych doświadczeń, także tych wypracowanych przez inne państwa i organizacje ${ }^{33}$.

Należy ponadto rozważyć prawne uregulowanie rozwoju ,usług wielu prędkości" w ramach państwa. Chodzi o to, aby umożliwić decydowanie o formie i zakresie świadczenia usług na niższym poziomie, bliżej usługobiorców, a w niektórych przypadkach nawet na poziomie zakładu administracyjnego. Aby ograniczyć dowolność w tym obszarze, działania te powinny być podejmowane w porozumieniu z właściwymi organami administracji publicznej. Dzięki temu będzie możliwe sprawne podejmowanie decyzji, z uwzględnieniem aktualnych warunków epidemicznych w miejscu świadczenia usługi. Zyskają na tym użytkownicy zakładów administracyjnych położonych w miejscowościach oddalonych od ognisk choroby i w których odnotowywana jest niewielka liczba zachorowań.

Wszelkie proponowane działania powinny uwzględniać najnowsze kierunki rozwoju polityki Unii Europejskiej w obszarze cyfrowym oraz kluczowe dziedziny unijnej strategii cyfrowej, których celem jest transformacja cyfrowa. W założeniu ma ona skutkować osiągnięciem do 2030 roku pełnej dostępności najważniejszych usług publicznych online (dla obywateli i przedsiębiorstw Unii), zagwarantowaniem dostępu do dokumentacji medycznej w formie elektronicznej

zarzadzanie informację $w$ perspektywie bibliologii i informatologii, red. S. Cisek, Kraków 2016, s. 127-143).

33 Zob. np. Rada Europy, The Internet, a public service accessible by everyone, https://www. coe.int/en/web/portal/public-service-accessible-by-everyone (dostęp: 6.07.2021); European Commission, Digital Public Services in the Digitel Economy and Society Index, https://digital-strategy. ec.europa.eu/en/policies/desi-digital-public-services (dostęp: 6.07.2021); O. Velsberg, U.H. Westergren, K. Jonsson, Exploring smartness in public sector innovation - creating smart public services with the Internet of Things, „European Journal of Information Systems” 29, 2020, nr 4, s. 350-368; M. Sourbati, "It could be useful, but not for me at the moment": older people, internet access and e-public service provision, „New Media \& Society” 11, 2009, nr 7, s. 1083-1100; B. Oppenheim et al., Assessing global preparedness for the next pandemic: development and application of an Epidemic Preparedness Index, „BMJ Global Health” 4, 2019, nr 1, s. 1-9; J.M. Kauzya, E. Niland, The role of public service and public servants during the COVID-19 pandemic, „United Nations Department of Economic and Social Affairs Policy Briefs" 2020, nr 79, s. 1-4. Zob. także postępowe projekty wyróżnione w konkursie Innowacyjny Samorząd 2021, https://innowacyjnysamorzad.pap. pl/laureaci/ (dostęp: 6.07.2021). 
wszystkim obywatelom Unii oraz korzystaniem przez $80 \%$ obywateli Unii z rozwiązań w zakresie cyfrowej tożsamości. Jej skutkiem ma być również usprawnienie działań sektora zdrowia i opieki ${ }^{34}$.

\section{Bibliografia}

Bazylak M., Churski P., Dawydzik A., Dutkiewicz R., Erbel J., Hausner J., Korta A., Kubalski G., Kudłacz M., Łoś A., Szałucki K., Wolański M., Węgrzyn B., Zachariasz I., Partycypacja spoteczna w samorzadzie terytorialnym w czasie epidemii i po, „Alert Samorządowy” 2020, nr 6.

Behr J., Gmina jako podmiot administracji świadczącej w zakresie usług niematerialnych, Warszawa 2019.

Behr J., Prawo do nauki w podmiotach leczniczych: analiza na przyktadzie publicznej szkoły podstawowej specjalnej, „Folia Iuridica Universitatis Wratislaviensis” 5, 2016, nr 2.

Behr J., Prywatyzacja ustug gminnych, [w:] Efektywność ekonomiczna jako cel prywatyzacji zadań z zakresu administracji świadczącej: studium administracyjno-prawne, red. J. Blicharz, R. Raszewska-Skałecka, Wrocław 2020.

Behr J., Udzial trzeciego sektora w świadczeniu gminnych ustug niematerialnych, [w:] Trzeci sektor i ekonomia społeczna: uwarunkowania prawne. Kierunki działań, red. J. Blicharz, L. Zacharko, Wrocław 2017.

Biernat S., Prywatyzacja zadań publicznych. Problematyka prawna, Warszawa-Kraków 1994.

Bigo T., Związki publiczno-prawne w świetle ustawodawstwa polskiego, Warszawa 1928.

Dlugotrwałe nauczanie zdalne w szkołach i uczelniach źle wptywa na psychike młodych ludzi, https://naukawpolsce.pap.pl/aktualnosci/news\%2C87027\%2Cekspertka-dlugotrwale-nauczanie-zdalne-w-szkolach-i-uczelniach-zle-wplywa-na.

Edukacja w czasie pandemii dyskryminuje dzieci i młodzież z niepetnosprawnościami - RPO wystapit do MEiN, https://www.rpo.gov.pl/pl/content/edukacja-dyskryminujaca-dzieci-i-mlodziez-z-niepelnosprawnosciami-w-czasie-pandemii.

European Commission, Digital Public Services in the Digitel Economy and Society Index, https:// digital-strategy.ec.europa.eu/en/policies/desi-digital-public-services.

Główny Urząd Statystyczny. Urząd Statystyczny w Szczecinie, Społeczeństwo informacyjne w Polsce w $2020 r$. Warszawa-Szczecin 2020.

Jazieh A.R., Akbulut H., Curigliano G., Rogado A., Alsharm A.A., Razis E.D., Mula-Hussain L., Errihani H., Khattak A., De Guzman R.B., Mathias C., Alkaiyat M.O.F., Jradi H., Rolfo Ch., Impact of the COVID-19 Pandemic on Cancer Care: A Global Collaborative Study, „JCO Global Oncollogy" 2020, nr 6.

Klonowiecki W., Zakład publiczny w prawie polskiem. Studjum prawo-administracyjne, Lublin 1933.

Kauzya J.M., Niland E., The role of public service and public servants during the COVID-19 pandemic, „United Nations Department of Economic and Social Affairs Policy Briefs” 2020, nr 79.

Konkurs Innowacyjny Samorząd, https://innowacyjnysamorzad.pap.p1/laureaci/.

Kuta T., Administracja ustug, Poznań 2000.

${ }^{34}$ Komunikat Komisji do Parlamentu Europejskiego, Rady, Europejskiego Komitetu Ekonomiczno-Społecznego i Komitetu Regionów Cyfrowy kompas na 2030 r.: europejska droga w cyfrowej dekadzie, COM/2021/.118 final, https://eur-lex.europa.eu/legal-content/pl/TXT/?uri=CELEX\%3A52021DC0118 (dostęp: 7.07.2021).

Prawo 333, 2021

(C) for this edition by CNS 
Kuta T., Rola administracji ustug $w$ zaspokajaniu potrzeb socjalno-bytowych i oświatowokulturalnych obywateli, [w:] Administracja publiczna u progu XXI wieku: prace dedykowane prof. zw. dr hab. Janowi Szreniawskiemu z okazji Jubileuszu 45-lecia pracy naukowej, red. Z. Niewiadomski et al., Przemyśl 2000.

Lipowicz I., Samorząd terytorialny jako podmiot administracji świadczącej, „Ruch Prawniczy, Ekonomiczny i Socjologiczny" 2015, z. 3.

Niewiadomski Z., Uwarunkowania ksztattu wspótczesnej administracji publicznej, [w:] System Prawa Administracyjnego, t. 1. Instytucje prawa administracyjnego, red. R. Hauser, Z. Niewiadomski, A. Wróbel, Warszawa 2010, s. 21.

Niżnik-Dobosz I., Zasada ochrony praw stusznie nabytych, [w:] Środki ochrony praw stusznie nabytych $w$ świetle Konstytucji RP i prawa Unii Europejskiej, red. P. Chmielnicki, H. Zięba-Załucka, Warszawa 2012.

Oppenheim B., Gallivan M., Madhav N.K., Brown N., Serhiyenko V., Wolfe N.D., Ayscue P., Assessing global preparedness for the next pandemic: development and application of an Epidemic Preparedness Index, „BMJ Global Health” 4, 2019, nr 1.

Posłuszny J., Ewolucja administracji świadczącej (na przykładzie szkolnictwa wyższego). Studium administracyjnoprawne, Rzeszów-Przemyśl 2004.

Posłuszny J., Istota i cechy administracji świadczącej, „Administracja: teoria, dydaktyka, praktyka” $2005, \mathrm{nr} 1$.

Problem wykluczenia cyfrowego w edukacji, „Ekspertyza” 3, https://oees.pl/wp-content/uploads/ 2020/04/Ekspertyza-3.pdf.

Rada Europy, The Internet, a public service accessible by everyone, https://www.coe.int/en/web/ portal/public-service-accessible-by-everyone.

Rak D., Petrowicz M., Pokojska W., Potrzeby szkoleniowe i kompetencje seniorów w zakresie korzystania z internetu, [w:] Inspiracje i innowacje: zarzadzanie informację w perspektywie bibliologii i informatologii, red. S. Cisek, Kraków 2016.

Rzecznik Praw Pacjenta, Prawa pacjenta w czasie COVID-19 zostały ograniczone, https://www. gov.pl/web/rpp/do-rzeczy-rzecznik-praw-pacjenta-prawa-pacjenta-w-okresie-covid-19-zostaly-ograniczone.

Sourbati M., 'It could be useful, but not for me at the moment': older people, internet access and e-public service provision, „New Media \& Society” 11, 2009, nr 7.

Śledzińska-Simon A., Analiza proporcjonalności ograniczeń konstytucyjnych praw i wolności. Teoria i praktyka, Wrocław 2019.

Środki finansowe na dodatkowe zajęcia wspomagajace dla uczniów po powrocie do szkół z nauki zdalnej, https://www.gov.pl/web/edukacja-i-nauka/srodki-finansowe-na-dodatkowe-zajecia-wspomagajace-dla-uczniow-po-powrocie-do-szkol-z-nauki-zdalnej.

Velsberg O., Westergren U.H., Jonsson K., Exploring smartness in public sector innovation - creating smart public services with the Internet of Things, „European Journal of Information Systems" 29, 2020, nr 4.

WHO Director-General's opening remarks at the media briefing on COVID-19 - 7 September 2020, https:/www.who.int/director-general/speeches/detail/who-director-general-s-openingremarks-at-the-media-briefing-on-covid-19---7-september-2020.

Zimmermann J., Zasada ochrony praw dobrze (stusznie) nabytych, [w:] Prawo administracyjne, Warszawa 2016.

Prawo 333, 2021

(C) for this edition by CNS 


\title{
Public Services during the COVID-19 Pandemic: An Analysis Taking into Account the Specificity of Providing Intangible Services
}

\begin{abstract}
Summary
The COVID-19 pandemic is one of many pandemics that humanity will have to face in the near future. It influences the functioning of public entities and social relations. One of the areas most affected by its effects are intangible services, the provision of which is among the main tasks of public-legal associations, which are the local government units. The manner and scope of providing public services has changed significantly. Due to the risk of further pandemics, it is important to identify as many problems and challenges as possible related to the provision of these services and to develop effective solutions for them, so that public entities are best prepared to operate in difficult conditions and that human and civil rights and freedoms are not violated. The paper identifies the main problems related to the provision of intangible services during a pandemic and suggests ways to solve them.
\end{abstract}

Keywords: public-law associations, COVID-19 pandemic, public services, intangible services, services exclusion, problems, de lege ferenda postulates. 